\title{
"SETTLING SOME VERY IMPORTANT PRINCIPLES OF COLONIAL LAW": THREE "FORGOTTEN" CASES OF THE $1840 \mathrm{~S}$
}

\author{
Mark Hickford*
}

This article reintroduces the "forgotten" cases of $\mathrm{R} v \mathrm{v}$ Taylor, Attorney-General v Whitaker and Scott $\mathrm{v}$ Grace and considers their specific historical contexts. They raise controversial questions about the extent of the New Zealand governor's ability to grant lands outside of the provisions of local ordinances and imperial statutes by using the prerogative. The article notes the flow-on effects of the policy lacuna created by these judgments. The judgments of Justice Chapman and Chief Justice Martin caused considerable unease on the part of the colonial government and policymakers in London as well as some New Zealand Company operatives. This in turn led to the subsequent legislative and policy efforts to qualify the reach of prerogative powers in colonies. The text of the cases is appended to this article.

\section{INTRODUCTION}

In the memory of New Zealand's early legal history, $R v$ Symonds ${ }^{1}$ stands as a singular fragment - a fossil that is estranged from its particular historical contexts ${ }^{2}$ and is now used as representing

* Crown Counsel, Treaty of Waitangi and International Law Issues Team, Crown Law Office, Wellington. The views expressed in this paper are personal to the author and not those of the Crown Law Office. Much of the research was conducted in the course of writing my doctoral thesis at the University of Oxford. I am grateful to Dr Paul McHugh, Sidney Sussex College, University of Cambridge, who prevailed upon me to undertake this article. I am indebted to the assistance and comments of Dr Ashley Gould, Consultant Historian, Crown Law Office and am also appreciative of the help of J Brent Parker, Damen Ward and Dr D M Loveridge.

1 (1847) NZPCC 387 (SC). Peter Spiller "Henry Chapman: First Supreme Court Judge of Wellington" (1989) 19 VUWLR 267, 276-277.

2 As explored in David V Williams "The Queen v Symonds Reconsidered" (1989) 19 VUWLR 385; Paul McHugh "The Common-Law Status of Colonies and Aboriginal 'Rights': How Lawyers and Historians Treat the Past", (1998) 61 Sask L Rev 393 ["The Common-Law Status of Colonies and Aboriginal 'Rights'"]; Paul McHugh "A Tribal Encounter: the Presence and Properties of Common-Law Language in 
foundational principles of aboriginal title at common law in New Zealand. ${ }^{3}$ It is treated as part of a respectable panoply of court decisions on common law aboriginal title that includes the familiar United States' Supreme Court decisions under Chief Justice Marshall, in the early nineteenth century, as well as a shopping list of other common law cases: Amodu Tijani v Secretary, Southern Nigeria, ${ }^{4} R v$ Sparrow ${ }^{5}$ and Mabo v State of Queensland (No 2) ${ }^{6}$ to name a few.

Symonds justifiably enjoys its significance as a considered judgment that introduced the Marshall Court jurisprudence of the United States to imperial New Zealand, and spoke in largish terms about the doctrine of "pre-emption" and native title requiring a "fair purchase" before it could be extinguished. ${ }^{7}$ Yet it belongs to a forgotten line of subsequent cases determined by Chief Justice Martin and Justice Chapman in the late $1840 \mathrm{~s}$, such as $R v$ Clarke, $R v$ Taylor, and one set of proceedings by Justice Chapman alone: Scott $v$ Grace. ${ }^{8}$ In this article I introduce three of these New Zealand Supreme Court cases $-R v$ Taylor, and the two Scott v Grace decisions - through their historical context. ${ }^{9}$ Henry Samuel Chapman undoubtedly saw Symonds as foundational but he

the Discourse of Colonization in the Early Modern Period" in Alex Calder, Jonathan Lamb and Bridget Orr (eds) Voyages and Beaches: Pacific Encounters, 1769-1840 (University of Hawaii Press, Honolulu, 1999) 114, 127-128 ["A Tribal Encounter"]; Mark Hickford Making 'Territorial Rights of the Natives': Britain and New Zealand, 1830-1847 (D Phil Thesis University of Oxford, 1999) 283-285 ["Making 'Territorial Rights of the Natives"'].

3 For example Ngati Apa v Attorney-General [2003] 3 NZLR 634 (CA) para 21 Elias CJ; 136, 141-142 Keith and Anderson JJ; Attorney-General v Ngati Apa [2002] 2 NZLR 661, 679 para 48 Ellis J (HC) (the Marlborough Sounds foreshore and seabed case); Te Runanga o Te Ika Whenua Inc Society v AttorneyGeneral [1994] 2 NZLR 20, 24 (CA) Cooke P; McRitchie v Taranaki Fish and Game Council [1999] 2 NZLR 139, 146, 158 (CA); Faulkner v Tauranga District Council [1996] 1 NZLR 357, 362 (HC).

4 Amodu Tijani v Secretary, Southern Nigeria [1921] 2 AC 399 (PC).

$5 \quad R v$ Sparrow [1990] 1 SCR 1075; (1990) 70 DLR (4th) 385 (SCC).

6 Mabo v State of Queensland (No 2) (1992) 175 CLR 1; 107 ALR 1 (HCA).

7 Te Runanga o Te Ika Whenua Inc Society v Attorney-General [1994] 2 NZLR 20, 24 (CA) Cooke P: "Chapman J also spoke of the practice of extinguishing native titles by fair purchase. An extinguishment by less than fair conduct or on less than fair terms would be likely to be a breach of the fiduciary duty widely and increasingly recognised as falling on the colonising power."

8 They are not, for instance, recorded in Peter Spiller, John Finn and Richard Boast A New Zealand Legal History (Brookers, Wellington, 2001); or in Peter Spiller The Chapman Legal Family (Victoria University Press, Wellington, 1992). Three notable exceptions to this "forgetfulness" are Peter Spiller, above n 1, 277, 66 (where the cases are listed); Guy Lennard Sir William Martin: The Life of the First Chief Justice of New Zealand (Whitcombe and Tombs Ltd, Christchurch, 1961) 43-45; and J Rutherford Sir George Grey, KCB, 1812-1898: A Study in Colonial Government (Cassell, London, 1961) 129-140 discussing $R v$ Taylor and $R$ $v$ Clarke in a summary fashion.

9 The advice of the judicial committee of the Privy Council is reported in (1851) NZPCC 516; 519-520 for an accessible summary of the New Zealand Supreme Court's decision in $R v$ Clarke. The Privy Council's advice is also reported at (1849-1851) 7 Moo PC 77-85 (PC). 
regarded it as first in a series of these legally interconnected cases, which he considered "great cases" in correspondence with his father. ${ }^{10}$ With the exception of the Scott v Grace litigation (given the absence of the Crown as a party in those proceedings), Justice Chapman listed these cases as "settling some very important principles of Colonial law on points not often agitated in any Colony - for it is seldom any Governor sets about to disturb the acts of his predecessors." 11

In introducing these cases, this paper's purpose is not to make claims about the correctness, truth or falsity of these cases through the anachronistic "condescension of posterity" as E P Thompson might have said, but rather to expose ways in which they stood in the muddy contexts of legal and political argument. ${ }^{12}$ When analysing legal sources historically one must be sensitive to the fashion in which these sources were used and situated within broader historical contexts. Rather than perceiving "law" as a relatively static and knowable doctrine that furnishes appreciably "correct" answers to legal problems when summoned, legal sources ought to be treated as often provisional ways of seeing and talking about the world as part of a set of political, commercial and intellectual "moves". ${ }^{13}$ This essay makes two central points. First, Justice Chapman and Chief Justice Martin developed a "strong" view of the prerogative as exercised via the colonial Governor where land grants received the Crown's imprimatur in the form of New Zealand's public seal irrespective of the provisions of the local ordinances. There is no doubt that their approach caused considerable unease and upset on the part of the colonial government and some New Zealand Company operatives who were especially concerned that the prerogative should not outrun the strictures of colonial ordinances on land grants and land policies premised on the controlled dispersal of settlement (whether by the Company or government) through high upset prices per acre. Their approach as

10 Chapman to Chapman senior (17 June 1849) Letter (Wellington, Alexander Turnbull Library, Letters of H S Chapman qMS-0420) 727. "I anticipated that it $[R v$ Symonds $]$ was of a nature to become an authority and to be quoted continually. This will keep my name before Ministers [in Britain] and sooner or later lead to my promotion": Chapman to Chapman senior (14 April 1848) Letter (Wellington, Alexander Turnbull Library, Letters of H S Chapman qMS-0419) 578.

11 Chapman to Chapman senior (17 June 1849), above n 10, 727.

12 For this methodological approach refer to D Armitage The Ideological Origins of the British Empire (Cambridge University Press, Cambridge, 2000) 5. It is an approach that derives from the leading work of J G A Pocock Politics, Language and Time: Essays on Political Thought and History (Chicago University Press, Chicago, 1989) 23-30; J Tully ed Meaning and Context: Quentin Skinner and His Critics (Princeton University Press, Princeton, 1988). It is employed in both Hickford, above n 2, and Mark Hickford "'Decidedly the Most Interesting Savages on the Globe': an Approach to the Intellectual History of Maori Property Rights, 1830-1850" (New Zealand Historical Association Conference, University of Canterbury, Christchurch, December 2001). The reference to E P Thompson is from his classic work The Making of the English Working Class (Penguin, London, 1963) 12: "I am seeking to rescue the poor stockinger, the Luddite cropper, the 'obsolete' hand-loom weaver ... from the enormous condescension of posterity."

13 J G A Pocock, above n 12, 23-30. See also J Tully Strange Multiplicity: Constitutionalism in an Age of Diversity (Cambridge University Press, Cambridge, 1995) 181-182; Richard Posner The Problems of Jurisprudence (Harvard University Press, Cambridge (Mass), 1990) 43, 47 and 49. 
judges revealed, for politicians at least, the unreliability of discrete legal proceedings in furnishing legal answers that would favour preferred Crown or Company policies. In that sense, Symonds stood out amongst the Supreme Court decisions of Taylor and Clarke as a case in which the Crown had succeeded. ${ }^{14}$ Second, the receptivity of Justice Chapman, in particular, to using United States' legal sources in colonial New Zealand is noted. However, it is argued that the jurisprudence of the United States Supreme Court on "native title" was not as warmly endorsed amongst imperial policymakers in London as some earlier legal-historical works might have implied. ${ }^{15}$ Rather, the evidence indicates that the Colonial Office in Britain was not in favour of using such law as a guide to policy on aboriginal property rights in New Zealand between 1830 and 1847. In short, therefore, the use of United States' law was contentious in certain areas, especially in relation to questions of Maori property rights.

For the three cases discussed here, the particular political context was that of George Grey's colonial administration seeking to upset various policies of Grey's predecessor Governor Robert FitzRoy in relation to land titles. As is appreciated with some notoriety, FitzRoy sponsored the passage of two proclamations in 1844 with the intention of permitting the waiver of Crown preemption in prescribed circumstances. ${ }^{16}$ On assuming the lieutenant-governorship from 18 November 1845, Grey distanced himself from his politically discredited predecessor through, inter alia, assailing the FitzRoy proclamations as injurious to the colony's condition and prospects. ${ }^{17}$ According to official reports, some 90,016 acres had been acquired at one penny per acre under the 10 October 1844 proclamation as at 13 June 1846, although the acreage secured under "waiver" certificates was principally granted in the vicinity of Auckland and not the New Zealand Company's

14 Acknowledging, of course, that the Crown ultimately succeeded in $R v$ Clarke before the Privy Council: (1849-1851) 7 Moo PC 77-85 (PC).

15 Paul McHugh The Aboriginal Rights of the New Zealand Maori at Common Law (PhD Thesis, University of Cambridge, 1987) 232-236; Paul McHugh The Maori Magna Carta: New Zealand Law and the Treaty of Waitangi (Oxford University Press, Auckland, 1991) 103-113; Michael Belgrave "Pre-emption, the Treaty of Waitangi and the Politics of Crown Purchase" (1997) 26 New Zealand Journal of History 23, 27: "As McHugh has argued there was no need to include these issues of [aboriginal proprietorship] in the Treaty [at Waitangi]; the [common law] doctrine [of aboriginal title] would have applied anyway"; M P K Sorrenson "Treaties and British Colonial Policy: Precedents for Waitangi" in William Renwick Sovereignty and Indigenous Rights: the Treaty of Waitangi in International Contexts (Victoria University Press, Wellington, 1991) 15-29. McHugh's later writings have suggested some increasing distance from his earlier stance. Significant contributions are "The Common-Law Status of Colonies and Aboriginal 'Rights'", above n 2, 428-429; "A Tribal Encounter", above n 2, 114-131; 127-128. Also discussions with Paul McHugh (the author, Cambridge University, 1999) and Paul McHugh "Proving Aboriginal Title" [2001] NZLJ 303, 304.

16 Refer to Proclamation, 26 March 1844 (London, Kew, Public Record Office, Colonial Office 209/27) folios 446a-447; Proclamation, 10 October 1844 (London, Kew, Public Record Office, Colonial Office 209/29) folios 21a-22. The "right of pre-emption" was recognised in several places, including Article Two of the Treaty of Waitangi and, implicitly, in the Land Claims Ordinance 1841.

17 George Grey became Governor-in-Chief from 30 November 1847. 
settlements further south. ${ }^{18}$ Furthermore, FitzRoy had authorised a number of Crown grants of land that were in excess of the maximum 2,560 acres that commissioners investigating land claims (based on alleged purchases from Maori) could recommend under the Land Claims Ordinance 1841 (session I, no. 2). He had also granted lands where there had been no report from a commissioner under the Land Claims Ordinance, as was the case in $R v$ Taylor and Attorney-General $v$ Whitaker \& Anor.

\section{SCOTT V GRACE - LAMBTON QUAY, WELLINGTON}

The Scott $v$ Grace proceedings of 1848, however, deserve recognition in that they occurred within the context of vying pretensions to legal title between those claiming property interests derived from the New Zealand Company and "old land claimants" relying on direct grants from the Crown. This litigation provides an insight into how the initially large question of extinguishing Maori property rights could readily fade into a voiceless backdrop for intra-Pakeha disputes regarding the interior legal landscape of Anglo-settlement.

The Scott proceedings were as much a complicated political contest about the authority of the colonial Governor as were the other decisions of the Supreme Court in Symonds, Taylor, and Clarke. The Colonial Office, in approaching the matter via a reference to the law officers of the Crown, further encouraged the New Zealand Company to bring the litigation in 1846 with a view to confronting the matter legalistically rather than politically. ${ }^{19}$ The then parliamentary undersecretary at the Colonial Office, Lord Lyttelton, advised the secretary of the New Zealand Company, Harington, that William Gladstone, the then secretary of state for colonies, had posed a case for the law officers of the United Kingdom. The case was developed "for the purpose of ascertaining their opinion upon several points relating to the validity of the grants recently issued to the New Zealand Company at Wellington and at Nelson in the Colony of New Zealand and of the separate grants which have likewise been made to certain parties not connected with the Company."20 A Company legal opinion provided by Charles Buller (a parliamentarian and New Zealand Company director), G J Turner and B Peacock in May 1846 had prompted the request for an opinion from the law officers of the Crown and accompanied the Colonial Office's case for the law officers. It had concluded that the grant in favour of the old land claimant, David Scott, would fail against the title derived from the New Zealand Company. ${ }^{21}$ Counsel were of the opinion that FitzRoy acted contrary to his

18 Making 'Territorial Rights of the Natives', above n 2, 278.

19 Lyttelton to Harington (16 June 1846) Letter (Archives New Zealand, New Zealand Company 1/4) folios $168-170$.

20 Lyttelton, to Harington (16 June 1846), above n 19, folio 168.

21 "Opinion of Counsel on the Deeds of Grant" in Messrs Few \& Co to Harington (30 May 1846) Letter in New Zealand Company Twentieth Report of the Court of Directors of the New Zealand Company Presented to the Annual General Court of Proprietors Held on the 29 $9^{\text {th }}$ May 1846 (New Zealand Company, London, 
instructions in making grants to Scott, to the manager of the Union Bank and George Young in Port Nicholson. The "instructions" were said to comprise a letter of Lord Stanley, secretary of state for the colonies (12 May 1842), to the Company. Lord Stanley's letter approved Governor Hobson's 6 September 1841 representation to the Company that it would receive a grant of land for any acre validly purchased from Maori. The opinion advised that it would be prudent for the Company not to accept the Crown grants until the questions in dispute had been settled. The Company's firm of solicitors, Messrs Few \& Co, added their own more extensive opinion in support of the view that the Company-derived titles would prevail at law. ${ }^{22}$ With such legal reasoning in support, therefore, there was sustenance for an approach to the Supreme Court of New Zealand with a view to testing the matter at law. This was abetted by sentiments of local company operatives in New Zealand itself where there was an understandable interest in clarifying land issues on the ground.

There was also perhaps a general sense developing that the Company could look forward to a rewarding political rapprochement with the government in London when the Tory ministry of Sir Robert Peel gave way in July 1846 to the Whig-led administration of Lord John Russell, especially with the congenial Whig paramount, the third Earl Grey (formerly Viscount Howick until his father's death in July 1845), as secretary of state for colonies. ${ }^{23}$ The senior Whig aristocrat, Viscount Palmerston, privately advised Lord John Russell in 1844 that "Charles Buller indeed said to a friend of mine at that time [in the last parliamentary session of that year], that Howick was the God of his idolatory". ${ }^{24}$ Whilst Palmerston recognised that the ardour of Buller's favourable sentiment might have abated subtly during $1844,{ }^{25}$ there is no doubt that Howick and his closest

1846) 257-258. Also see New Zealand Company, Special Committee (30 May 1846) Minutes (London, Kew, Public Record Office, Colonial Office 208/188) folios 420-421.

22 Messrs Few \& Co to Harington (24 June 1846) Letter (London, Kew, Public Record Office, Colonial Office 209/48) folios 432-437.

23 Charles Buller and the New Zealand Company enjoyed a close association with Earl Grey by the mid-1840s (refer to Making 'Territorial Rights of the Natives', above n 2, 250; 257; 269-270; 288). See also William Parker Morrell British Colonial Policy in the Age of Peel and Russell (Clarendon Press, Oxford, 1930) 202203, which is sensitive to the importance of interpersonal networks to politics in this period. For "liberal" and "whig" politics in the mid-nineteenth century see Jonathan Parry The Rise and Fall of Liberal Government in Victorian Britain (Yale University Press, New Haven (Conn), 1993) and Peter Mandler Aristocratic Government in the Age of Reform: Whigs and Liberals, 1830-1852 (Oxford University Press, Oxford, 1990).

24 Palmerston to Russell (20 December 1844) Letter (London, Kew, Public Record Office, Papers of Lord John Russell 30/22/40) folio 41.

25 Palmerston to Russell (20 December 1844), above n 24, folio 41: "I think indeed that before the end of the Session one saw plain indications that the idolatrous zeal of Buller \& Hawes had somewhat abated \& that they had discovered, what other People knew long ago, that Howick for all his talent which nobody can deny him, is intirely [sic] deficient in some qualities indispensable for a leader of a party however select ...". 
parliamentary supporter, Benjamin Hawes, strongly sympathised with New Zealand Company enterprises in New Zealand throughout $1844-1850 .^{26}$

The proceedings in Scott $v$ Grace were intended to clarify the situation of grantees claiming titles derived from the New Zealand Company, especially in its township settlements - a political issue not only for New Zealand but also for London and the New Zealand Company lobby based there. Unsurprisingly, purchasers from the New Zealand Company had made capital outlays on improvements such as buildings within their township settlements at Wellington (from 1839), Nelson and New Plymouth. According to New Zealand Company accounts, the sums involved could be considerable, particularly in areas such as Lambton Quay and Thorndon Quay in the Port Nicholson district. Chapman noted that, the land concerned in the Scott case "was in a part of the town [in 1840] where shops are, and where land then let for $£ 1$ per annum per foot frontage".27 Matters were complicated by the fact that a putative Crown grant of land to the Company in 1845 of 71,900 acres for Port Nicholson district or 151,000 acres in Nelson on the part of FitzRoy specifically exempted lands validly claimed on the basis of purchases occurring prior to those of the Company. ${ }^{28}$ The large issue, then, was the status of titles derived from the New Zealand Company's system of land sales from 1839. Unsurprisingly, the Company wished to ensure that its titles were secure and commercially viable. It had already endeavoured unsuccessfully to enter into a confidential arrangement with Sir Robert Peel's ministry whereby the Crown would either purchase the Company's claimed property in New Zealand for $£ 300,000$ or lend it $£ 100,000$ for the purpose of realising its titles. ${ }^{29}$

Thus, the resort to law was part of a larger political strategy to secure the Company's territorial position and occurred in the context of Company dissatisfaction with FitzRoy's grants of 1845. As such, legal practice operated within a fluid and intertwined metropolitan and colonial context - the

26 For instance, Hawes to Russell (26 July 1845) Letter (London, Kew, Public Record Office, Papers of Lord John Russell 30/22/40) folios 228-229: "I hear that you disapproved of my New Zealand speech. I own it was one meant for the Company \& that, because I very much identify the welfare of the Company with that of the Colony. It is because there is a company here that I think there is a better chance of successful colonization there. And, - friends of the Company begged me to do [nothing?] but attack. If I had spoken as I intended I certainly should not have met with your disapproval (emphasis in original)."

27 Chapman to Chapman senior (20 May 1848) Letter (Wellington Alexander Turnbull Library, qMs-0419) 586.

28 See Port Nicholson Crown Grant (29 July 1845) (London, Kew, Public Record Office, Colonial Office 209/35) folios 7-10; Deed of Grant, Nelson (29 July 1845) (London, Kew, Public Record Office, Colonial Office 209/35) folios 11-14. Harington, Secretary of the New Zealand Company, to Gladstone (28 February 1846) Letter in New Zealand Company Twentieth Report of the Court of Directors of the New Zealand Company Presented to the Annual General Court of Proprietors held on the 29th May (New Zealand Company, London, 1846) 217-221.

29 Buller to Peel (15 February 1845) "Confidential Memorandum" (London, British Library, Peel Papers, Add Mss 40,559) folios 44-49a. 
tendency to read a simple disjunction between a London-centred imperial metropole and a distant colony can be overplayed. ${ }^{30}$ The Colonial Office was an important audience for New Zealand Supreme Court decisions, especially in so far as George Grey and the New Zealand Company were concerned, not to mention any third parties aggrieved at court decisions and seeking to impress upon Colonial Office officials the necessity for favourable political responses to their interests whether court decisions favoured their positions or not. Court decisions became a feature of political engagement with land issues. Copies of the Court decisions were conveyed to London, occasionally with extensive accompanying documents and queries, often eliciting much internal Colonial Office comment. ${ }^{31}$ Hence, the usually intense particularism of court proceedings (a specific set of events arising in, say, Wellington with the Scott litigation) was certainly in evidence but it occurred against the backdrop of overarching imperial policy concerns and intensive lobbying efforts by third parties.

Scott involved a parcel of township land with frontage on Lambton Quay. Grace resisted Scott's action to recover possession of that piece of land in Grace's occupation and comprised within a larger parcel that Scott claimed by virtue of a deed of Crown grant from FitzRoy in July $1845 .{ }^{32}$ Scott, a flax trader in the Wellington area in the early 1830 s, had purported to purchase land with frontage on what would become Lambton Quay from Maori on 31 March 1831 for a keg of powder of 100 pounds weight. This he valued at $£ 8$ and 15 shillings. Scott's purchase was an "old land claim" and therefore came under the Land Claims Ordinance 1841 (session I, no. 2), as it constituted

30 The emphasis in parts of the imperial historiography is now moving towards methodological (and increasingly forensic) approaches that connect metropole and colony. For example, F Cooper and A L Stoler "Between Metropole and Colony: Rethinking a Research Agenda" in F Cooper and A L Stoler (eds) Tensions of Empire: Colonial Cultures in a Bourgeois World (University of California Press, Berkeley, 1997) 15; Catherine Hall Civilising Subjects: Metropole and Colony in the English Imagination 1830-1867 (Polity, Cambridge, 2002); John Darwin "Imperialism and the Victorians: the Dynamics of Territorial Expansion" (1997) 112 English Historical Review 614; Making 'Territorial Rights of the Natives', above n 2, 302-308; Zoë Laidlaw "Networks, Patronage and Information in Colonial Governance: Britain, New South Wales and the Cape Colony, 1826-1843" (D Phil Thesis, University of Oxford, 2001) (publication forthcoming in Manchester University Press).

31 For example, refer to the responses to $R v$ Symonds in Earl Grey to Hawes (3 November 1847) Minute (London, Kew, Public Record Office, Colonial Office 209/53) folio 38a; Earl Grey to Grey (3 December 1847) (London, Kew, Public Record Office, Colonial Office 209/53) folio 44. Others in London also commented on New Zealand cases. For instance, in the case of the Scott v Grace decisions of the Supreme Court, the Colonial Land and Emigration Commissioners requested that another legal case for opinion be presented to the law officers of the Crown in late 1849 with a view to querying the reasoning of the New Zealand Supreme Court: T C W Murdoch and Sir Frederic Rogers to T Frederick Elliot (14 November 1849) (Archives New Zealand, New Zealand Company 1/8) folios 638-650.

32 One acre and a half of land granted to David Scott was excepted from the 29 July 1845 FitzRoy deed of grant to the New Zealand Company of 71,900 acres in the vicinity of Port Nicholson. Various charts, including one prepared by Charles Heaphy, indicates that the block covered much of the northern end of Lambton Quay, including the area now traversed by Woodward Street: (London, Kew, Public Record Office, Colonial Office 209/69). 
an attempt to directly purchase property from Maori in the period before the 14 January 1840 proclamation in Sydney of Sir George Gipps, the Governor of New South Wales, and that of William Hobson at Kororareka in the Bay of Islands on 30 January 1840. (These proclamations declared that the Crown would not acknowledge as valid any title to land, which was either not derived from or confirmed by a subsequent Crown grant). ${ }^{33}$

Scott left the Cook Strait area in 1834 and did not return until May 1840 just before the New Zealand Company's town sections were distributed. Town sections were sold and resold and an acre of one of them was cut into small lots of which Grace acquired one. Buildings estimated to be valued at between $£ 4,000$ and $£ 5,000$ had been constructed on the one and a half acres in favour of Scott that were excepted from the 1845 Crown grant of 71,900 acres to the Company in Port Nicholson. ${ }^{34}$ That deed was issued under the public seal of the colony with FitzRoy's authority. According to Grace's affidavit evidence at the second Scott case of June 1848 he had purchased the land at public auction in 1840 for $£ 76: 17 \mathrm{~s}$ and was then put into possession. Grace alleged to have erected buildings which cost him $£ 800$ before they were destroyed by the calamitous Wellington fire of 1842 , following which he erected a brick building costing nearly $£ 400 .{ }^{35}$ Grace had since purported to convey the land subject to the dispute to William Fox of Nelson. Fox was appointed Attorney-General of the New Munster province of New Zealand in February 1848 and was nominated successor to William Wakefield as principal agent for the New Zealand Company in New Zealand following the latter's death in September 1848. Daniel Bell Wakefield, brother of William Wakefield, the principal agent for the New Zealand Company in the colony, represented Grace as lead counsel in the litigation. ${ }^{36}$ Justice Chapman had been, until 1842, proprietor-editor of the New Zealand Company's journalistic centrepiece in London, The New Zealand Journal, and had also served as a land agent for the New Zealand Company's claimed titles in New Zealand,

33 Gipps to Normanby (9 February 1840) Letter (London, Kew, Public Record Office, Colonial Office 209/6) folio 6: "The third proclamation [of 14 January 1840] was issued, in order to put an end, as far as possible, to the speculations in New Zealand lands, which were then being carried on in Sydney." See also "Copies or Extracts of Despatches from the Governor of New South Wales, Bearing the Date the $9^{\text {th }}$ and $19^{\text {th }}$ Days of February 1840; Together with a Copy of the Reply of the Secretary of State thereto" (Great Britain Parliamentary Papers 1840 (xxxiii (582)) 575-585.

34 William Wakefield to the Editor of the New Zealand Spectator (13 August 1845) Letter enclosed with Wakefield to Harington, Secretary of the Company (8 September 1845) Letter in the Twentieth Report of the Court of Directors of the New Zealand Company Presented to the Annual General Court of Proprietors held on the $29^{\text {th }}$ May, 1846, above n 21, 232.

35 (Archives New Zealand, New Zealand Company 1/4) folios 277-281: "Memorial of Mr Grace unto the Rt Hon Earl Grey, Her Majesty's Secretary of State for the Colonies". See also the statement of Alfred Domett, colonial secretary of the province of New Munster enclosed in Grey to Earl Grey (31 January 1849) Letter (Archives New Zealand, New Zealand Company 1/4) folio 273 and following. Grace's affidavit in the 28 June 1848 Scott $v$ Grace decision recorded the expenditure for the later building as $£ 300$ rather than $£ 400$.

36 Handwritten outline of Daniel Wakefield's argument in the May 1848 case (Archives New Zealand, New Zealand Company 131/6). 
travelling into northern England at the request of its directors in mid-1841 to disseminate information on the colony and the objects of the Company. ${ }^{37}$

Scott had signalled his intention to take possession of his grant in August $1845^{38}$ and succeeded in his action to recover possession from Grace with Justice Chapman presenting his judgment on 13 May 1848. ${ }^{39}$ Chapman commented, "[t]his judgment will create a disturbance of property amounting to $£ 5,000$ or $£ 6,000$ but the law is in favour of the grantee and Fitzroy's mischief cannot be rid of". ${ }^{40}$ An attempt on the part of Grace at a stay of execution concluded with yet another decision of Justice Chapman albeit this time in favour of Grace on 28 June 1848 enabling him to bring a suit against Scott for compensation. ${ }^{41}$ As with the decision in Taylor, for instance, Scott v Grace addressed the extent to which the Colonial Governor could make grants of land other than in accordance with the relevant land claims ordinance, specifically the Land Claims Ordinance 1841 (session I, no. 2). In the first Scott v Grace decision, Justice Chapman observed that a letter of Governor Hobson dated 6 September 1841, professing "that the Company would receive a grant of all such lands as may by any one have been validly purchased from the natives; the Company compensating all previous purchasers according to a scale to be fixed by a local ordinance", could not avail Grace's case because, on the authority of $R v$ Symonds, "the Crown [could] convey nothing to the subject, except under the public seal of the colony".42 His Honour explained that "[no] interest, howsoever slight, passed to the New Zealand Company or those claiming under it by the letter in question and therefore it cannot affect the operation of the Land Claimants Estate Ordinance [session III, no. 20]". The Land Claimants Estate Ordinance provided that where any claim to land had been confirmed by a Crown grant under the Lands Claims Ordinance 1841, the legal estate in the land was deemed to have been in the grantee from the date of purchase. As such, Scott was

37 Making 'Territorial Rights of the Natives', above n 2, 169 n 5.

38 Refer to George Moore and others to William Wakefield (7 January 1846) Letter (Archives New Zealand, New Zealand Company 131/6). The date of David Scott's notice was 29 August 1845.

39 Report of Justice Chapman's initial judgment (Archives New Zealand, New Zealand Company 3/8) folios 183-185. For William Wakefield's report on the 13 May 1848 case to the Secretary of the New Zealand Company in London, refer to Wakefield to Secretary of the New Zealand Company (30 May 1848) Letter (Archives New Zealand, New Zealand Company 3/8) folios 215-219.

40 Chapman to Chapman senior (20 May 1848) Letter (Wellington, Alexander Turnbull Library, qMs-0419) 586.

41 Justice Chapman's judgment (28 June 1848) (Archives New Zealand, New Zealand Company 3/8) folios 352-355.

42 Russell to Elliot, Torrens, and Villiers (14 January 1840) Letter (London, Kew, Public Record Office, Colonial Office 385/19) folio 246, where Lord John Russell observed: "In each colony the Governor holds a commission enabling him, in the name and on behalf of the sovereign, to convey the waste lands to the purchasers of them. Except by a grant under the public seal of the Colony issued in pursuance of such commission no private person can establish a valid title to such lands. It is not intended to disturb this ancient and convenient practice." 
entitled to rent from Grace, the occupier, backdated to the time of purchase. The view of the Company's legal counsel and solicitors in England had not prevailed.

In Chapman's view, provided there were no express words limiting the Governor's power to grant Crown lands in a colonial ordinance, the prerogative power exercised on behalf of the Crown remained intact and preserved under the 1840 Charter for New Zealand. The assumption was that the Land Claims Ordinance 1841 merely defined the powers of the commissioners appointed under its authority or purporting to act in accordance with it without circumscribing the power of the Crown under the Charter of 16 November 1840 to grant land outside of the ordinance. The Charter of 1840 empowered the Governor to make grants of Crown lands "subject nevertheless to such provisions as may be in that respect contained in any instructions which may from time to time be addressed to him by us for that purpose". 43 Alfred Domett, the colonial secretary for New Munster province (1848-1853), found Chapman's approach to be objectionable, as it did not, to his mind, coincide with the temper and apparent statutory purposes of the imperial Waste Lands Act 1842, let alone the various land claims ordinances. ${ }^{44}$ That is, for Domett the Crown was separate from its agent, the governor, and "regulations [whether ordinances or an Act of the Imperial Parliament] are on the whole restrictive and were intended to impose limitations on the alienation by the Governor of the Crown property." 45 Domett added that Chapman's "express words" rule "is made to defeat its own object, and lessen the prerogative power of the Crown over its own lands." Crown policy, said Domett, was that of "checking as much as possible the gratuitous disposal of land, or any disposal of it in undue quantities, and of keeping up its price for the purpose of systematic colonisation". ${ }^{4}$

The meaning of sections 6 and 7 of the Land Claims Ordinance 1841 was a key to Grace's arguments presented with a view to clarifying the legal position of purchasers of New Zealand Company titles, especially within the heart of that Company's embryonic townships. Section 6 of the Land Claims Ordinance 1841 required that the Land Commissioners could not recommend any grant of land that "comprehended" any headland, promontory, bay or island that may be required

43 Great Britain Parliamentary Papers 1841 (xvii (311)) 32: "Charter for erecting the Colony of New Zealand, and for creating and establishing a Legislative Council and an Executive Council, and for granting certain powers and authorities to the Governor for the time being of the said Colony."

44 Waste Lands Act 1842, ("An Act for regulating the Sale of Waste Land belonging to the Crown in the Australian Colonies") 5 \& 6 Vict, c 36 did not apply to New Zealand from 28 August 1846 by virtue of Sale of Waste Lands Amendment Act 1846 (UK), 9 \& 10 Vict, c 104, s 11.

45 Statement of Alfred Domett (31 January 1849), above n 35, folio 273.

46 Statement of Alfred Domett (31 January 1849), above n 35, folio 273. 
after 1841 for any purpose of defence or for the site of any town or village reserve or for any other purpose of public utility. ${ }^{47}$

Under section 7 of the Land Claims Ordinance 1841 the Commissioners could not propose the grant to any claimant of land which may be required for the site of any town or village or for the purposes of defence or for any other purposes of public utility. Furthermore, the Commissioners could not propose the grant to any individual in any land of a similar character which they may be directed to reserve by the Governor of New Zealand. Wellington, after all, was a township. These arguments did not assist Grace in resisting Scott's application to recover possession in the court hearing of 13 May 1848 but Chapman considered them sufficiently persuasive to justify staying proceedings at a subsequent fixture on 28 June 1848 in order to permit compensation for the value of the buildings and other improvements on the land in favour of Grace. For Justice Chapman a stay accorded with the requirements of equity in view of sections 6 and 7 of the Land Claims Ordinance 1841, the letter of Governor Hobson of 6 September 1841 (subsequently published in the New Zealand Gazette), the fact that Grace, in improving the land, would have felt reassured because of the improvements made to neighbouring township properties by businesses. Scott, said Justice Chapman, would "enjoy the benefit of [Grace's] ameliorations, and it [was] for him to compensate [Grace] - not to the extent of every shilling which may have been expended, whether judiciously or injudiciously - but on the more equitable principle of the value which comes into his hand". In arriving at this result, Justice Chapman encouraged counsel in their use of United States sources on equity, such as Joseph Story's Commentaries on Equity Jurisprudence, to complement his distillation of English legal principles. He said that: "In considering this case, learned counsel have drawn largely upon the equitable jurisprudence of the United States of America; and I have thought it incumbent on me to examine and remark upon the passages to which they referred, as well as some others which occurred to myself." 48 Chapman referred to a bevy of cases, including Cud $v$ Rutter, ${ }^{49}$ and Hobs $v$ Norton. ${ }^{50}$

According to Domett, an attempt on the part of New Munster province to settle Grace's claims in the course of the proceedings with $£ 1,200$ failed when Grace requested $£ 7,000$ as compensation in

47 The Land Commissioners could not recommend a grant in excess of 2,560 acres unless specially authorised by the Governor with the advice of the Executive Council. That left open the question of the Governor's prerogative beyond acts that purported to be done in accordance with the Land Claims Ordinance 1841.

48 Scott v Grace (28 June 1848) (Archives New Zealand, New Zealand Company 3/8) folio 355.

49 Cudv Rutter (1719) 1 P Wms 569; 24 ER 521 (incorrectly referred to in the report of Scott v Grace as Cut v Ruther $1 \mathrm{P}$ Wms 57).

50 Hobs $v$ Norton 2 Chan Cas 128; 22 ER 879 (for the assumption that a purchaser will not be relieved against the title of the true owner who, being ignorant of his own title at the time, encourages the purchaser to lay out money). 
reply. ${ }^{51}$ Settlement proved elusive even though an arrangement was reached on 20 September 1849 between Grace's successor in title, William Fox, and Scott for the extinguishment of Scott's controversial grants through purchase on the part of the New Zealand Company. ${ }^{52}$ It is not clear what money (if any) was paid to Grace. The cost of extinguishing the Crown grant to Scott was estimated at $£ 2,912.00$ for the land and rentals plus $£ 3,100$ for legal expenses, mesne profits and incidentals. The matter of payment continued to perplex participants in the dispute well into the 1850 s and may have even received comment in the General Assembly of the House of Representatives on 24 June $1856 .{ }^{53}$ There appeared to be doubt as to whether the defunct New Zealand Company or the relevant provincial government ought to have debts arising from the matter. Records indicate considerable expenditure on legal advice and attendances throughout the 1840 s and 1850 s in excess of the probable value of the claim.

Finally, Scott v Grace is of interest because it reinforces - as with Symonds - the degree to which Justice Chapman was familiar with, and receptive to, United States' jurisprudence in circumstances where it could be deployed relevantly in New Zealand. ${ }^{54}$ Justice Chapman apparently had access to United States' legal sources within his carefully nourished personal library and was long familiar with the jurisprudence of the Marshall Court in the United States on native title. Indeed, he had introduced the Marshall Court's jurisprudence on "native" or "aboriginal" title to the discussion of New Zealand affairs on behalf of the New Zealand Company in early 1840 in an article for The New Zealand Journal in London. ${ }^{55}$ Referring to his judgment in Symonds, he reported to his father, "I am very familiar with the history of our Intercourse with the American Indians for 200 years." He added, "Martin will of course deliver his own Judgment but I have exhausted the whole subject - for besides a very complete opinion in [the] form of a Judgment - I sent him a great number of notes and some books which will be very serviceable to him." $56 \mathrm{He}$

51 Statement of Alfred Domett (31 January 1849), above n 35, folio 273 and following.

52 Articles of Agreement between David Scott, William Fox and Charles Siested (20 September 1849) (Archives New Zealand, New Zealand Company 131/6).

53 Extract from Nelson Examiner (16 August 1856) Nelson (Archives New Zealand, New Zealand Company 131/6).

54 As discussed in Making 'Territorial Rights of the Natives', above n 2, 284-285. On the use of United States jurisprudential sources in the Anglo-settler colonies of the British Empire see generally P Karsten Between Law and Custom: 'High' and 'Low' Legal Cultures in the Lands of the British Diaspora - the United States, Canada, Australia, and New Zealand, 1600-1900 (Cambridge University Press, Cambridge, 2002) 498-503; Mark Hickford "Between Law and Custom: 'High' and 'Low' Legal Cultures in the Lands of the British Diaspora - the United States, Canada, Australia, and New Zealand, 1600-1900: Shorter Notice Review" (2003) 118 English Historical Review 817, 818.

55 Henry Chapman "The English, the French, and the New Zealanders" (4 April 1840) The New Zealand Journal 49.

56 Chapman to Chapman senior (15 June 1847) Letter (Wellington, Alexander Turnbull Library, qMs-0419) 437; 433-436 on Chapman's library. 
certainly had access in New Zealand to the main transmitter of Marshall Court jurisprudence for English legal and political audiences, namely James Kent's multi-volume text entitled Commentaries on American Law. Both Martin and Chapman cited from the third volume at lecture 51 in the Symonds decision. ${ }^{57}$ The 1828 edition of Kent's text was evidently in use in Britain and was favoured not merely in judicial opinions but also in pamphleteering and other rhetorical exercises aimed at persuading a variety of audiences. ${ }^{58}$ The jurist, Travers Twiss, would acknowledge the use of such American case law in the imperial context of New Zealand in discussing ius gentium, the law of nations, in 1846. Twiss, Herman Merivale's successor in the Drummond chair of political economy at the University of Oxford, observed: "A further accessorial right of settlement has, in modern times, been recognised by the practice of civilised nations in both hemispheres, namely, a right of pre-emption from the aboriginal inhabitants in favour of the nation which actually settled in the country." 59 He added that, "It is this right which Great Britain asserts against all other civilised nations in respect to New Zealand, and which the United States of America assert against all other civilised nations in respect to the native Indians." ${ }^{60}$

It is important to appreciate that, in the early legal history of colonial New Zealand, the New Zealand Company (and Chapman as one of its publicists, legal counsel and land agents in England in 1840) staunchly advocated the use of United States Supreme Court jurisprudence on native title as a guide to what property rights in Maori ought to be recognised. Specifically in 1840, this case law was deployed to defend Company acquisitions from Maori on the basis that it had acted responsibly on behalf of Crown interests in furthering "systematic colonisation" through introducing immigrants rather than acting as a purely speculative land-hunter. ${ }^{61}$ In this vein, the Company used United States' decisions as evidence of "ancient law" that could also justify its actions in acquiring territories for settlement in New Zealand on the grounds of Cook's "discovery" and mapping of the islands in 1769. It presented itself as having exercised the Crown's right of "pre-emption" through extinguishing Maori customary title or, at the very least, as having a claim to compensation from the Crown in the event of it not having done so adequately in respect of its recently established settlement in Wellington.

57 (1847) NZPCC 387, 390; 393 (SC).

58 See, for instance Lord Eliot MP, House of Commons in Hansard's Parliamentary Debates (third series, London, 1840) column 527-528 citing Chancellor Kent; W Martin England and the New Zealanders: Remarks upon a Despatch from the Right Hon Earl Grey to Governor Grey dated Dec 231846 (Bishop's Auckland Press, Auckland, 1847) 19-20. James Kent Commentaries on American Law (O Halstead, New York, 1826). Making 'Territorial Rights of the Natives', above n 2, 235-236; 284-285; 286.

59 Travers Twiss The Oregon Question Examined, in Respect to the Facts and the Law of Nations (Longman, Brown, Green, Longmans, London, 1846) 176.

60 Twiss, above $\mathrm{n} 59$.

61 Making 'Territorial Rights of the Natives', above n 2, 176-183. 
Chapman's article in The New Zealand Journal of April 1840 observed that, in view of the Marshall Court's decision in Johnson $v$ M'Intosh, ${ }^{62}$ "discovery gave the Government by whose subjects or authority it was made, a title to the country and a sole right of acquiring land from the natives, as against all European powers (emphasis in original)". ${ }^{63}$ Chapman added that it "must be clear, that the rights reserved to the native tribes could only be of a modified character, but whether those rights were abridged or extensive - whether they were confined to a mere right of occupation, or amounted to something deserving the name of sovereignty, was a question which did not affect the relation between the discovering nation and civilised powers". 64 Seven years later, in commenting on Symonds and its use of United States' jurisprudence, Chapman would say that "I think this opinion or quasi-judgment of mine will advance my reputation as a Colonial Judge and a lawyer."65 Interestingly, he thought his views on "native title" in Symonds coincided with those of the third Earl Grey's 23 December 1846 despatch to George Grey, in quoting from Thomas Arnold's 1831 article in the Englishman's Register, which said that "so much does the right of property go along with labour that civilized nations have never scrupled to take possession of countries inhabited only by tribes of savages - countries which have been hunted over but never subdued or cultivated". 66 Chapman commented that the "principles that [the third Earl Grey] lays down in relation to the native title to the land are precisely what I have asserted."67 Other commentators would vigorously disagree with the view that relevant United States' case law entailed aboriginal property rights limited to land that was physically occupied and cultivated, indicating that the application of the Marshall Court decisions on aboriginal proprietary rights at common law was not conclusive in the arena of either policy or legal reasoning, as it was capable of sustaining such discordant interpretations. ${ }^{68}$

62 Johnson $v$ M'Intosh (1823) 8 Wheat 543.

63 Chapman, above n 55, 49.

64 Chapman, above n 55, 49 (The omitted footnote in Chapman's article was citing Worcester v State of Georgia (1832) 6 Pet 515 in support of this passage).

65 Chapman to Chapman senior (15 June 1847), above n 56, 438.

66 Earl Grey to Grey (23 December 1846) Letter (London, Kew, Public Record Office, Colonial Office 209/47) folios 271-272 (emphasis in original) citing T Arnold "The Labourers of England (11 June 1831): Englishman's Register" in A P Stanley (ed) The Miscellaneous Works of Thomas Arnold, DD (B Fellowes, London, 1845) 155, 156-157; Making 'Territorial Rights of the Natives', above n 2, 288-292.

67 Chapman to Chapman senior (15 June 1847), above n 56, 437-438.

68 Making 'Territorial Rights of the Natives', above n 2, ch 3 and 4 in particular. For examples of varying interpretations of the legal and practical significance of the use of United States' jurisprudence on "native title" at common law in New Zealand refer to Hadfield to George Grey (10 September 1847) Letter (Auckland Public Library, Grey Papers H1(3)) folios 98-101 and Louis Alexis Chamerovzow, The New Zealand Question and the Rights of Aborigines (T C Newby, London, 1848) 201-205 (citing specifically from James Kent, above n 58). 
New Zealand Company representatives first referred to United States' jurisprudence of the Marshall Court applying to New Zealand before a House of Commons select committee in mid1840. Edward Gibbon Wakefield produced the law report of the Marshall court's 1823 decision of Johnson $v$ M'Intosh before the select committee on 17 July $1840 .{ }^{69}$ His audience included Robert Vernon Smith, then parliamentary undersecretary at the Colonial Office under the Whig secretary of state for colonies, Lord John Russell. It was relatively conventional for parliamentary undersecretaries at the Colonial Office to sit on select committees where imperial questions were in issue in order to represent ministerial interests. James Stephen, permanent undersecretary at the Colonial Office from 4 February 1836 until 3 May 1848, dismissed the jurisprudence in a minute addressed to his political superior, Robert Vernon Smith, in the context of Wakefield having referred to the Johnson $v$ M'Intosh case. Stephen commented that: "The case of Johnson and MacIntosh [sic] proves that a grant from an Indian Tribe of lands on the state of [Ohio] would confer on the practice no valid title in defezance of a Title derived under a grant from the United States." ${ }^{70}$ He continued with the comment that, "[i]t shows that the whole territory over which those tribes wandered was to be regarded as the property of the British Crown in right of discovery and of conquest - and that the Indians were mere proprietors [or "mere possessors of the soil"] on sufferance. Such is American law."71 For Stephen, an empire of variations based on policy decisions that might be specific to New Zealand, South Australia or Upper Canada (not necessarily driven by law) was very much to be preferred. ${ }^{72}$ But the New Zealand Company was striving for an "empire of uniformity" in New Zealand where Anglo-settlement occurred that was based on the universal application of United States' law regarding indigenous populations. Stephen insisted on the inapplicability of these American sources: ${ }^{73}$

69 Wakefield, evidence (17 July 1840) Great Britain Parliamentary Papers 1840 (vii (582)) 511.

70 Stephen to Vernon Smith (28 July [1840]) Letter (London, Kew, Public Record Office, Colonial Office 209/4) folio 343 (the incorrect year "1839" is pencilled at the top of the folio page in the Colonial Office records. R Vernon Smith was not at the Colonial Office as parliamentary under-secretary until 2 September 1839 and, whilst the provenance of the memorandum remains difficult to ascertain precisely, its date of "28 July 1840" would fit with the hearings of the House of Commons' select committee chaired by Lord Eliot MP, which reported on 30 July 1840).

71 Stephen to Vernon Smith (28 July [1840]), above n 70, folio 343.

72 Making 'Territorial Rights of the Natives', above n 2, 107-108; 179-186; 233-257; 267-272; 283-292; 295301.

73 Stephen to Vernon Smith (28 July [1840]), above, n 70, folios 343-343a. Emerich de Vattel Le Droit des Gens, Ou Principes de la Loi Naturelle, Appliqués à la Conduite \& aux Affaires des Nations \& Des Souverains [The Law of Nations; or, Principles of the Law of Nature: Applied to the Conduct and Affairs of Nations and Sovereigns] (two volumes, A Leide, Aux Depens de la Compagnie, Neuchâtel, 1758; new edition (translation) by Joseph Chitty, S Sweet \&c, London, 1834) featured much more regularly in imperial discussions about Maori property rights than the texts of Samuel Pufendorf and Hugo Grotius, as observed in Making 'Territorial Rights of the Natives', above n 2, 37-39; 155; 173-174; 286. It was a favoured source on the law of nations in the 1830s and 1840 s, not least of all because of its accessibility, having recently 
[Emerich de] Vattel, in the interest of Holland, laid down the principle of open fisheries. Mr Marshall, great as he was, was still an American, and adjudicated against the rights of the Indians.

The Colonial Office would continue to oppose the usefulness of the Marshall Court decisions in respect of Maori property interests until the advent of the third Earl Grey's administration as secretary of state from July $1846 .{ }^{74}$ Earl Grey was familiar with the Marshall Court's jurisprudence by virtue of his leading a House of Commons' select committee on the New Zealand situation in 1844 and personally writing its report. ${ }^{75}$ The report of that committee endorsed the American position as a statement of "correct" principles of colonial law. ${ }^{76}$ Yet, the Colonial Office's opposition was not unusual. Various elements within the House of Commons did not approve of the assumed application of Marshall court jurisprudence to Maori in the three-day debate in 1845 against Sir Robert Peel's government on the "New Zealand question". Sir Howard Douglas, a member for Liverpool, exhorted: ${ }^{77}$

[Viscount Howick's select committee of 1844 stated that a "new fundamental principle of colonial law has ... been discovered"]. It is this, - "That the uncivilised inhabitants of any country have but a qualified dominion over it, or a right of occupancy only; [...]" I should like to ask where this principle of colonial law is to be found? I find it not in Vattel, nor in Vaughan's Reports, nor in Stokes, nor in Blackstone. [...] I suspect I know the origin of this new fundamental principle of colonial law. It comes, I think, from the land in which the Black Man is a slave, and the Red Men of the forest are

been republished in English under the editorship of Joseph Chitty in 1833-1834. For an excellent discussion on Vattel and other writers on ius gentium see R Tuck The Rights of War and Peace: Political Thought and the International Order from Grotius to Kant (Oxford University Press, Oxford, 1999).

74 Stanley to FitzRoy (13 August 1844) Letter Great Britain Parliamentary Papers 1845 (xxxiii (1)) 3: "I am not sure that were the question one of mere theory, I should be prepared to subscribe unhesitatingly, and without reserve, to the fundamental assumption of the Committee [of Viscount Howick]; and I am sure that it would require considerable qualification, as applicable to the aborigines of New Zealand. There are many gradations of "uncivilized inhabitants", and practically, according to their state of civilization, must be the extent of rights which they are allowed to claim, whenever the territory on which they reside is occupied by civilized communities. And it cannot be denied that, among "uncivilized nations", the New Zealanders hold a very high place, certainly far above the inhabitants of the other Australian colonies".

75 For example, Howick, Journal (Durham University Library, Palace Green, Gre/V/C3/10) entries for 2 July 1844; 4 July 1844; 5 July 1844; 9 July 1844; 12 July 1844: "I have not made much progress with my [New Zealand] report"; entry for 13 July 1844: "I staid [sic] the whole afternoon at home working hard at my NZ report".

76 "Report: Select Committee Appointed to Inquire into the State of the Colony of New Zealand; and into the Proceedings of the New Zealand Company" Great Britain Parliamentary Papers 1844 (xiii (556)) vi, for example: "If native rights to the ownership of land had only been admitted when arising from occupation, there would have been no difficulty in giving at once to the settlers secure and quiet possession of the land they required $[\ldots] "$

77 A Corrected Report of the Debate in the House of Commons on the $17^{\text {th }}, 18^{\text {th }}$, and $19^{\text {th }}$ of June 1845 on the State of New Zealand and the Case of the New Zealand Company (London, 18 June 1845) 124. 
driven and hunted from their lands, as the Seminole and other Indians have been, according to certain adjudications that Indians have no property to the soil or their respective territories than that of mere occupancy.

\section{R V TAYLOR - SEABED AND FORESHORE}

$R v$ Taylor ${ }^{78}$ decided on 16 July 1849 , concerned the Crown bringing a writ of scire facias $^{79}$ (as in Symonds) to set aside a FitzRoy grant dated 15 July 1844 purporting to convey Kawau Island north of Auckland. No commissioner ever reported in favour of the grant. Commissioner Godfrey had investigated the grantee's alleged "purchase" from Maori before 1840 and he recommended that no grant issue. The fact that a grant issued contrary to a commissioner's report under the Land Claims Ordinance 1841 and to the provisions of that ordinance, formed one of several key planks to the Attorney-General's argument. A second basis for the suit was that the governor had acted in excess of his authority. The grantee, James Beattie, almost immediately "sold" the island to another party and the North British Australasian Loan and Investment Company (also referred to in the correspondence as the "Aberdeen Company") then commenced copper mining operations on the island. The company's representative was John Taylor who was based in Sydney. The company built works on the island and a wharf, projecting below high water mark at the point where the subterranean lode reached the coastline, for the convenience of shipping copper ore from Kawau Island.

The Chief Justice, William Martin, concluded that the ordinance did not fetter the governor's prerogative power to grant lands. He said that the "only restriction imposed by the Ordinance is upon the commissioners: they are forbidden to recommend a grant of more than 2,560 acres without a special authority enabling them to do so". ${ }^{80}$ Chapman observed that the imperial Waste Lands Act 1842 did not invalidate the grant because it no longer applied to sales of land in New Zealand by virtue of section 11 of $9 \& 10$ Vict, c104 (its non-application to New Zealand was effective from 28 August 1846). Because it was repealed, he treated it as having never applied in law to the colony on

78 Great Britain Parliamentary Papers 1850 (xxxvii (1280)) 3-16.

79 The writ of scire facias was a judicial writ founded on some record that required the person against whom the writ was brought to show why the party bringing the writ should not have the advantage of the record in judgment. For case law on scire facias suits refer to Sir Oliver Butler's Case (1681) 2 Ventr 344 (Ch) affirmed (1685) 3 Lev 220 (HL); The Queen v Eastern Archipelago Company (1853) 22 LJQB (NS) 196, 213 (QB) Lord Campbell CJ; (1853) 23 LJQB (NS) 82, 88-89 (Ex Ch) Martin B in particular.

80 Great Britain Parliamentary Papers 1850, above n 78, 5 Martin CJ. Also, "The conclusion to which I come, upon a review of the whole of this Ordinance is, that the functions of the commissioners were not judicial, but ministerial; that it was their business to collect information for the use of the governor, and to submit proposals for his consideration, not to take away his discretion, but to enable him to exercise his discretion safely; the power of ultimately deciding what were the cases that came within the benefit of the Queen's declaration, still rested (as I conceive) with the governor." 
the basis of cases such as Kaye $v$ Goodwin. ${ }^{81}$ Chapman concluded on the question of the prerogative that "knowing as I do, how jealous our law is of any restriction on the prerogative without the clear and express words of a statute, and how much disposed the highest Courts in the realm are to support the prerogative by every reasonable construction to the Queen's honour, and the subjects' advantage", the grant was within the power and authority of the governor to execute in July 1844. ${ }^{82}$ This was a reprise of his conclusions on legal principle in Clarke, where he found: ${ }^{83}$

1. The Charter of 1840 places in the hand of the Governor (among other things) so much of the Royal

Prerogative as relates to the making of Grants of waste land. 2. The prerogative can only be taken away or restrained within the colony by the express words of an Ordinance (or statute). 3. The Land Claims

Ordinance not only contains no such express words, restraining the exercise of the prerogative so vested in the Governor, but contains a clause expressly saving the prerogative. 4. Hence Governor FitzRoy, even if he departed from the spirit of the Ordinance in making a Grant of more than 2560 acres, could (in the absence of any false suggestion by the grantee himself) legally make such a grant.

Chapman considered that the theory of the limited authority of the governor was untenable as the "granting power [in respect of lands] is part of the royal prerogative lawfully delegated to the governor". ${ }^{84} \mathrm{He}$ viewed the office of a colonial governor as, in principle, precisely analogous to that of the lord lieutenant of Ireland and noted that distance or remoteness from the metropolitan centre of empire in London would necessarily imply that a colonial governor had the capacity to grant lands under the prerogative. Joseph Chitty's text of the prerogative powers of the Crown was enlisted in Chapman's judgment together with George Chalmers' tome on English jurisprudence. ${ }^{85}$

81 Kaye v Goodwin (1830) 6 Bing 576, 582-583 Tindal CJ: "I take the effect of repealing a statute to be, to obliterate it as completely from the records of the parliament, as if it had never passed; and it must be considered as a law that never existed, except for the purposes of those actions which were commenced, prosecuted, and concluded whilst it was an existing law."

82 Great Britain Parliamentary Papers 1850, above n 78, 14.

$83 R$ v Clarke (1848) (SC) (London, Kew, Public Record Office, Colonial Office 209/63) folios 146 and following; 20 of the report. Of interest in relation to the imperial Waste Lands Act was Chapman's observation to his father that "[o]ne of the points not raised [in $R v$ Clarke] was that the grant was bad as being against the provisions of the Australia Land Sales Act. At the time that was believed by the Governor and the Attorney-General to be a valid objection, but not being raised was not noticed either in argument or in our Judgment. In the case I now send you [ $R v$ Taylor], it is shown to be untenable on account of the repeal of the Act in [Aug] 1846 ...": Chapman to Chapman senior (24 August 1849) Letter (Wellington, Alexander Turnbull Library, qMs-0420) 742.

84 Great Britain Parliamentary Papers 1850, above n 78, 13 Chapman J.

$85 \mathrm{~J}$ Chitty A Treatise on the Laws of the Prerogatives of the Crown; and the Relative Duties and Rights of the Subject (Joseph Butterworth \& Son, London, 1820) 35: "Nor can there be any doubt that the King may enable the governor to grant lands, franchises, and possessions in the colonies." (footnote: "And see Stokes 195"). Chalmers Opinions of Eminent Lawyers on Various Parts of English Jurisprudence, Chiefly 
Part of the grant to the Aberdeen Company involved the foreshore of Kawau Island. Although the Taylor case does not refer to that particular context, it exercised the opinions of the Colonial Office and George Grey considerably. James Stephen's successor as the permanent undersecretary of the Colonial Office, Herman Merivale, supposed in January 1849 that, "it may be taken for granted that according to maxims of English common law the Crown is in strictness owner of the beach between high and low water mark in the colonies as well as in England, subject only to the rights of the public to use it for landing to \&c, that a grant of "an island"... would not by those words convey the beach to the grantee". ${ }^{86}$ Merivale continued with a sense of dramatic irony: "Still, no one can be surprised that the owners of the island should think themselves perfectly safe in making reasonable use of the beach, \& for the public benefit as well as their own; above all in New Zealand where it may be supposed there is room enough for every one" 87

Additional complications occurred because of yet another FitzRoy grant dated 3 September 1845 near Kawau Island to some 27 acres of seabed in fee simple, a part of which covered the undersea portion of the copper ore seam and adjoined the Aberdeen Company's title to the island. It also included that "portion of the beach [of Kawau Island] between high \& low water mark which was most important to Taylor as being situated exactly where his load reached the sea (emphasis in original)." 88 The purpose of the grantees, as Herman Merivale noted from the vantage point of the Colonial Office in London, was "not to work a mine discovered by themselves ... but to work the lode already discovered \& used by Taylor, out of the limits of his grant (emphasis in original)". ${ }^{89}$ The grant had been made to Frederick Whitaker and Theophilus Heale, both members of the Legislative Council of New Zealand, in exchange for other land amounting to 27 acres previously held in fee by them in Auckland where FitzRoy's government wished to construct a fort. ${ }^{90}$ A

Concerning the Colonies, Fisheries and Commerce of Great Britain (two volumes, Reed and Hunter, London, 1814).

86 Merivale to Hawes "Case of Messrs Whitaker \& Heale" (21 or 29 January 1849) Memorandum (London, Kew, Public Record Office, Colonial Office 209/61) folio 36.

87 Merivale to Hawes (21 or 29 January 1849), above n 86, folios 35a-36.

88 Merivale to Hawes (21 or 29 January 1849 ), above n 86, folios 36-36a.

89 Merivale to Hawes (21 or 29 January 1849), above n 86, folios 36; 35a-36; 36-36a.

90 This aroused some controversy and further exacerbated relations between FitzRoy and the land commissioner William Spain, see William Spain to Andrew Sinclair, colonial secretary, Auckland (12 September 1845) Letter (London, Kew, Public Record Office, Colonial Office 209/36) folios 133a-135a : "I $\mathrm{am}$ at a loss to understand how the Governor can consider that 'arrangements for the exchange of land are now under existing circumstances inapplicable', - when His Excellency within the last few days, issued a Crown Grant to Messrs Heale and Whitaker, two of His Excellency's Legislative Councillors, of certain portions of land below high water mark surrounding the Island of Kawau - (originally granted, entire and without exceptions, to other parties) in exchange for a certain allotment in the Town of Auckland lately the property of the 'New Zealand Banking Company'"... (emphasis in original). 
banking company had previously owned the lot in Auckland upon which a fortified area would be constructed. It had been under contract for sale to the Crown when Governor FitzRoy sought to renege on the agreement as to the form of payment and to pay for the lot with an exchange of land in view of the parlous state of the Crown's finances. Notably, the colonial administration's revenue from land titles and Crown grants for the financial year commencing 1 April 1845 was a mere $£ 2,500 .{ }^{91}$ The New Zealand Banking Company, however, refused to accept payment in land. Frederick Whitaker, a director of the bank, along with his partner, Theophilus Heale, acquired the Auckland parcel from the New Zealand Banking Company and entered into an arrangement with FitzRoy for the exchange of existing Crown land on the understanding that they could mine the property which they would receive. ${ }^{92}$ Despite Taylor protesting to the colonial government on behalf of the Aberdeen Company, the Attorney-General in Auckland, William Swainson, was of the view that the putative grant below high watermark was not objectionable. ${ }^{93}$ Yet the grant issued to Whitaker and Heale included, as Herman Merivale observed from London in 1849, "part of the very wharf which Taylor had built: not only an obvious and serious injury but one for which T[aylor] could obtain no compensation inasmuch as the wharf having been originally in strict law an encroachment on Crown Land, the Crown had now given it to Whitaker."94 The Colonial Office was aware that, at common law, Attorney-General v Parmeter ${ }^{95}$ was a precedent to the effect that exclusive use of the foreshore was not possible in view of public rights of passage over it. In that

91 "Estimate of the Probable Expenditure [and Revenue] of the Government of New Zealand for the Financial Year, 1845-1846, Commencing $1^{\text {st }}$ April 1845 and Ending 31 $1^{\text {st }}$ March 1846" (London, Kew, Public Record Office, Colonial Office 209/34) folios 82-87.

92 Whitaker to Sinclair, colonial secretary, Auckland (15 August 1845) Letter (Archives New Zealand, IA15/6)

93 Opinion of the Attorney General enclosed with Sinclair, colonial secretary, Auckland, to Taylor (15 October 1845) Letter (Archives New Zealand, IA15/6). Also Swainson (13 October 1845) Minute (Archives New Zealand, IA15/6): "I have re-considered the point in this case - and I am of the opinion that the Grantee of Land at Kawau has not the shadow of a claim to any Land below High-water mark - that such land is the property of the Crown - and that it may be disposed of in the same manner as any other Crown land within the colony. The writer of this Protest cannot be aware that it is by an act of Grace only that Grant extends him down to High-water mark the Land Claims Ordinance ses[sion]n 1 no. 2 c.6 expressly prohibiting the Commissioners from recommending the Grant of any Land situate on the sea-shore within 100 feet of Highwater mark."

94 Merivale to Hawes (21 or 29 January 1849), above n 86, folio 38 .

95 Attorney-General v Parmeter (1811) 10 Price 378 (ExCh). For brief references refer to Coulson and Forbes on the Law of Waters Sea, Tidal, and Inland and Land Drainage (6 ed, Sweet and Maxwell, London, 1952) 68; S Moore A History of the Foreshore and the Law Relating Thereto (Stevens \& Haynes, London, 1888) 258, 438, 463, 626, 651, 712; and Stephen Jourdan Adverse Possession (Butterworths, London, 2003) para12-26. 
case, subsequently affirmed by the House of Lords in Parmeter v Gibbs, ${ }^{96}$ Lord Chief Baron Macdonald held that: 97

It is perfectly clear that all the soil under the salt water between high-water mark and low-water mark is the property of the Crown. Such property has certainly been (as it may be) communicated in a great many instances to the subject, but that is always subservient to the public right of the King's subjects generally. It is compared by Lord Hale, with his usual simplicity, to the case of a highway. The private right of the Crown may be disposed of, but the public right of the subject cannot, even if it be within this grant.

It was acknowledged that "there might be a grant of the soil; but such grant must be considered as subject to the public right, which cannot be disturbed."98 It was notable that the facts in Parmeter concerned Portsmouth Harbour, which was then intensively used and required for naval ships of the line. The representative of the Aberdeen Company in Sydney, Taylor, also cited the Parmeter decision in his 19 September 1845 protest to the colonial administration at Auckland regarding the issue of the grant of submerged land to Frederick Whitaker and Theophilus Heale. Nevertheless, Taylor overstated the effect of Parmeter in asserting that the Crown's right to the foreshore was not a proper subject of a grant to third parties at all "but a mere trust for the entire public". 99 Swainson, in an opinion of 15 May 1848 answered a series of questions posed, including: "Can the Governor under the circumstances stated Grant the Land lying under such portion of the sea?" The second part to that question was: "And if so, what effect has such Grant in reference to the Sea lying above the land - is the sea also granted, or is the right still issued [?] to all Her Majesty's subjects of passing and repassing upon this portion of the sea?" He answered the question succinctly: "I am of opinion that the Governor can grant the land in question: but that any public obstruction, or the obstruction of any ancient right of usage, invested upon the land of the Grantee, would be liable to removal". ${ }^{100}$ Yet, in considering the Crown grant to Whitaker and Heale from the vantage point of

96 Parmeter $v$ Gibbs (1813) 10 Price 412 (HL) Lord Eldon LC.

97 Attorney-General v Parmeter, above n 95, 399-401 Macdonald CB; 405 Macdonald CB: "Perhaps I might stop here at once and say, if in point of fact these ports and creeks, and part of the port of Portsmouth, is comprehended in the grant, that is by no means what the Crown could grant, so as to affect the jus publicum, which is the right of the subject universally".

Attorney-General v Parmeter, above n 95, 401.

99 Taylor to Sinclair, colonial secretary, Auckland (19 September 1845) (Archives New Zealand, IA15/6): "I am referred by my professional adviser to a case named in the margin [Attorney-General v Parmeter (1811) 10 Price 378] decided in the Exchequer in the year 1822 [sic] and affirmed in the House of Lords as fully bearing on this view of the case, but I desire to be understood as resting my objection chiefly on the ground that Her Majesty ... would not authorise the issue of such a Grant at the mouth of a mine opened by the Grantees of the Island, and to the prejudice and obstruction of operations commenced by them on the faith of the original Grant".

100 Swainson (15 May 1848) Opinion (Archives New Zealand, IA15/6). 
1849, Herman Merivale concluded that legal norms did not necessarily provide answers to questions that ultimately required a policy resolution. Merivale illustrated this appreciation in stating: "Whether this strange grant to $\mathrm{W} \& \mathrm{H}$ was good at all - Whether it would have been valid in England, considering the interference with a landing used by the public (Attorney-General $v$ Parmeter 10 Price) - Whether, if valid, in England, it would have been so in a colony - whether it may be good in part and bad in part - these are questions which it is now quite useless to consider". ${ }^{101}$ As a principle of law, therefore, there was no fundamental objection to the Crown conferring title to the seabed on a subject either at the Colonial Office on in the opinion of the Attorney-General in Auckland, William Swainson.

The grant to Frederick Whitaker and Theophilus Heale was ruled invalid in a Supreme Court hearing in November 1846 on the grounds that it breached the imperial Waste Lands Act $1842 .{ }^{102}$ The object of the Waste Lands Act was, as expressed in section 2, to ensure that the conveyance or alienation occur by way of sale and that the sale be conducted in accordance with the legislation's requirements. Chief Justice Martin held that this invalidated the grant. T Frederick Elliot of the Colonial Land and Emigration Commission later noted, in commenting on the case, that exchanges of one parcel of land for another had become "common in New Zealand", and "they could be legally effected in settling any claims for land which were of earlier date than the Land Sales Act, for all such claims were exempted from its operation". ${ }^{103} \mathrm{~T}$ F Elliot observed that the case of Messrs Whitaker and Heale was distinguishable because it arose after the passage of that legislation. Technically, the Whitaker and Heale claim for an exchange did not arise out of an "old land claim" but concerned an acquisition of land that had been made well after 1840 - the cut-off point for "old land claims" (direct purchases from Maori). In short, then, there could have been no sale within the meaning of the Waste Lands Act, as there had merely been an exchange of one property for another.

Before the Taylor decision of 1849, however, Whitaker and Heale lobbied the British Government directly for the reinstatement of their grant in the wake of the Supreme Court's adverse decision given that the Waste Lands Act 1842 no longer applied to New Zealand from 28 August 1846. The decision in favour of reinstatement was duly obtained albeit with some discomfort on the part of George Grey, which the Colonial Office sought to assuage. ${ }^{104}$ The decision to reinstate the

101 Merivale to Hawes (21 or 29 January 1849), above n 86, folio 38 .

102 Attorney-General v Whitaker \& Anor (17 November 1846) Supreme Court, Auckland (Archives New Zealand, IA15/6). Closing statements of counsel are reported in (26 September 1846) 69 New Zealander. The exact grant was 27 acres and two roods. A map of the seabed grant can be found at (London, Kew, Public Record Office, Colonial Office 209/60) folios 268 and following. The warrant to sue out "scire facias to set aside the grant" was applied for in September 1846.

103 T F Elliot to Hawes (19 January 1849) Memorandum (London, Kew, Public Record Office, Colonial Office 209/61) folio 10.

104 For example, Merivale to Hawes (11 October 1848) Letter (London, Kew, Public Record Office, Colonial Office 209/60) folios 147-148: "It [the reply to George Grey] would consist, I think, of three propositions, 
grant was made on the advice of the Secretary of State for Colonies in Britain, Earl Grey, without direct reference to the New Zealand authorities. Part of the rationale was that where private persons had outlaid considerable expense "in reliance on the solemn Acts of the Representative of the Crown [FitzRoy]", it was deemed "very hard that they should forfeit their property because of any errors of Law and Judgment on the part of the highest local authority". ${ }^{105}$ On the faith of Earl Grey's direction in support of the reinstatement of the seabed grant, extensive investment was made in steam machinery in England with a view to transporting it to New Zealand for use in submarine mining operations.

With both parties allegedly unable to protect their mining operations from inundation by the sea without trespassing on the other party's property, operations were ceased and employees discharged. The upshot was that the Aberdeen Company purchased the Whitaker-Heale grant at a cost of $£ 5,000$ in order to secure its commercial operations. ${ }^{106}$ It then requested compensation in a direct approach to the Colonial Office, specifically a request that the foreshore near the mine should be secured to the company against any further encroachments. The secretary of state for colonies, Earl Grey, informed Governor Grey that he considered the request for "compensation" reasonable. He stated that, "[t]he Crown can have no interest in such seashore, farther than this: to prevent individuals from using over it such exclusive powers as might either injure navigation or impede the public in the ordinary enjoyment of it, for passing and repassing and the like."107 His Lordship continued: "But this being attended to, I think the grantee of land adjoining the sea has a right to expect that the fore-shore will not be granted away to any other person by the Crown, as any such grant may materially abridge or interfere with his enjoyment of the adjoining ground."108 In responding to Earl Grey's direction, George Grey instructed the then Lieutenant-Governor of New Ulster province, Robert Wynyard (subject to Swainson's concurrence as Attorney-General), to guarantee to the Aberdeen Company that "no portion of the fore-shore of the Island of Kawau shall henceforth be granted away by the Crown....". ${ }^{109}$ On Swainson's recommendation, the issue was settled with an endorsement on the original grant in favour of the Aberdeen Company's predecessor in title on Kawau Island deeming the grant to extend to low water mark, but that this would be subject to a

first that the decision on the case of Messrs Whittaker [sic] and Heale was very carefully weighed with a full knowledge of all the circumstances, and that Lord Grey thinks that the restitution of their Lot was required by justice: secondly that Governor Grey will have found on receiving the additional Instructions about Exchanges, that it is purely permissive, requiring also the sanction of the Secretary of State, and that he may rest assured that there is no ground for apprehending that the inhabitants of New Zealand will be deprived of the advantage of the established modes of dealing with Land nor the principle of sale will be subverted; ...".

105 T F Elliot to Hawes (19 January 1849), above n 103, folios 11a-12.

106 Alexander Jopp to Earl Grey (2 June 1851) (Archives New Zealand, IA15/6).

107 Earl Grey to George Grey (12 June 1851) Despatch no 51 (Archives New Zealand, IA15/6).

108 Earl Grey to George Grey (12 June 1851), above n 107.

109 Grey to Wynyard (11 February 1852) (Archives New Zealand, IA15/6). 
right of the public to use the foreshore for navigation, landing, and passing or repassing. ${ }^{110}$ The endorsement was added to the deed of grant on 27 October 1853.

\section{CLARKE AND THE PREROGATIVE}

Against this background, the Privy Council's hearing of the $R v$ Clarke appeal was undoubtedly important but restricted to its facts. In Clarke the critical issue for the Judicial Committee of the Privy Council was that a grant of FitzRoy in favour of the missionary George Clarke senior to the extent of 5,500 acres (deed of grant dated 16 May 1844) was issued on the basis of the Land Claims Amendment Ordinance (session III, no 3). Thus, the grant in question was founded upon the report of a Commissioner (Fitzgerald) pursuant to a specific ordinance and was contrary to an earlier report of 13 May 1843 authored by two Commissioners (Godfrey and Richmond), under the Land Claims Ordinance 1841 (session I, no 2) recommending a grant no more than 2,560 acres. As the United Kingdom's Attorney-General observed there was no argument to the effect that the Commissioner was specially authorised by the Governor, with the advice of the Executive Council, to recommend a greater quantity of land than 2,560 acres to be granted to the respondent, George Clarke, as would be permitted under section 6 of the Land Claims Ordinance 1841. There was no appearance for George Clarke and the Privy Council ultimately found in favour of the Crown. Strictly speaking, the Privy Council left open the vexed question of whether the authority of the Governor could be exercised to make grants outside of the provisions of land claims ordinances. Nevertheless, it would seem implicit from the Privy Council's comments that "this is not a grant professing or intended to be made, as a matter of bounty or grace from the Crown, but it is only intended as a confirmation of that report, which was made under the authority of the ordinance", that their Lordships held the view that the Governor's authority under the Charter of 1840 for New Zealand was not affected. ${ }^{111}$ More precisely though, their Lordships did not feel any need to give an opinion.

In New Zealand at the time, the pro forma document for a Crown grant commenced with the prefatory words "[w]hereas, one of Our Commissioners appointed to hear, examine, and report upon Claims to Land obtained by Purchase from the Aboriginal Inhabitants of the Colony of New

110 Swainson (15 April 1852) Memorandum (Archives New Zealand, IA15/6).

$111 R v$ Clarke (1849-1851) 7 Moo PC 77, 84; 13 ER 808, 811 Rt Hon T Pemberton Leigh. Their Lordships advised that the "grant is founded upon the report, and the report is founded upon the Ordinance", adding that it "is clearly contrary to the terms of the Ordinance, and, therefore, the grant must fall, and the judgment upon the scire facias must be for the Crown [ibid, 811]." For the developing decision to recommend an appeal to the judicial committee on the suggestion of Governor Grey see Herman Merivale, permanent undersecretary at Colonial Office (27 January 1849) Minute (London, Kew, Public Record Office, Colonial Office 209/63) folios 92-93; Hawes to Solicitor of the Treasury (12 February 1849) (London, Kew, Public Record Office, Colonial Office 209/63) folios 222-222a; Earl Grey to Grey (31 March 1849) (London, Kew, Public Record Office, Colonial Office 209/63) no 22; Gairdner to Merivale (28 March 1849) Minute (London, Kew, Public Record Office, Colonial Office 209/63) no 22: "Mr Merivale. The instruction has [been] given to the Treasury Solicitors to prosecute the appeal, but it still remained to communicate with the Governor". 
Zealand, have reported that ...". In the amended grant of 1853 to the successors in title of James Beattie in the Taylor case, for instance, the passage after "whereas" had been deleted but the formula "[n]ow know ye, that We, of Our Special Grace, for Us, Our Heirs and Successors, do hereby Grant unto the said James Forbes Beattie ..." was retained, thereby stressing the point that the grant was not dependent on a report from land claims commissioners but was given under the royal prerogative. Interestingly, this deletion was not evident in the version of the original grant given to James Beattie in July 1845, a copy of which was transmitted to London, as the FitzRoy grant still purported to be based on the procedures of the Land Claims Ordinance 1841.112 I suspect, but cannot be certain, that the Privy Council's decision in Clarke had an impact on the practice of Grey's administration given the apparent deletion of the prefatory reference to a commissioner's report in the revised grant of 1853 that extended the extent of the grant to low water mark. At the very least, Grey's government was sufficiently alive to the problems of representing a reliance on commissioners' recommendations when none had been provided or the eventual grant was contrary to such recommendations. In the matter of Clarke, the words "[w]hereas, one of Our Commissioners appointed to hear, examine, and report upon Claims to Land obtained by Purchase from the Aboriginal Inhabitants of the Colony of New Zealand, have reported that ..." appearing in the Crown grant in question had not been deleted. ${ }^{113}$ The argument in favour of Clarke at the Supreme Court was that the validity of the 5,500-acre grant rested on the report of a Commissioner, a critical factor in the case on appeal.

In the Privy Council's hearing of Clarke, the Attorney-General expressly raised the question of the extent of the Governor's prerogative in submissions but the Privy Council refrained from dealing with the issue. Still, Governor Grey felt vindicated by the outcome in Clarke, although, as Chapman observed after the Supreme Court ruling in Clarke, his point on the Governor's prerogative and Crown grants was not essential to the decision of Chief Justice Martin. ${ }^{114}$ The Privy Council had not needed to address it either.

In the aftermath of Clarke, Chapman did not appear to resile from his position that the Governor could exercise a general prerogative power to grant Crown lands provided that there was no express restriction placed on that power via an ordinance or the charter of a colony. Chapman dealt with the status of instructions on a recurrent basis, as in his paper on mechanisms used to restrain Governors

112 For example, refer to Deed of Grant to James Forbes Beattie (11 July 1845) (London, Kew, Public Record Office, Colonial Office 209/61) folios 110-111.

113 Compare with Nelson Deed of Grant (London, Kew, Public Record Office, Colonial Office 209/35) folios 11-14, which claimed to be made in pursuance of a Commissioner's report (William Spain).

114 Chapman to Chapman senior (17 June 1849), above n 10, 729. 
in making grants of land in "excessive quantities" of 1852.115 In that paper, as in his judgment in Clarke in 1848, Chapman considered instructions as private directions, morally binding on a Governor, as an expression of the royal will. The Crown retained the sole remedy of dealing with an infraction of instructions on the Governor's part. Instructions, said Chapman, were not "intended to take away any portion of the powers once given under the Great Seal [as with the Charter of 1840]". ${ }^{116}$ In Clarke, Chapman noted "I believe I am correct in saying that instructions have not been recorded in any Colony; their character as a private instrument between the Crown and the Governor being carefully kept in view, the Crown retaining in its own hands the sole remedy in the sure case of infraction". ${ }^{117}$ In his paper of 1852 he commented: "So long as Instructions are a mere private instrument not recorded or published I am of the same opinion (see $R v$ Clarke) but it is clearly open to argument whether if such instructions be published and recorded as they were under General Murray's Commission - they ought not to be deemed effectual to bind the subject notwithstanding they are not under the great seal - by which alone Lord Coke says the King can grant revoke or even command [underlining in original]". ${ }^{118}$ In Murray's Commission of 1763, the relevant instructions were to be published in the province of Quebec itself for the notice of third parties. Chapman studiously avoided any reference to the Privy Council's advice of 15 May 1851 in $R v$ Clarke (assuming that he was aware of it when preparing his paper on the powers of colonial governors) but, in any event, the Privy Council had not directly addressed the question of the extent of the prerogative to grant lands in colonial New Zealand.

Nevertheless, the consistent message of Chapman's comments in 1848 and subsequently in 1852 was that the powers of the Governor, as recognised under the Charter of 1840, remained intact. Chapman's reasoning on the prerogative, therefore, underlying Clarke and Scott v Grace did not seem to have been especially unhinged by the Privy Council's advice. In any event, a political settlement rather than legal process was resorted to in order to provide the desired level of clarity. Political resolution of the fraught matter of titles in New Ulster province (including the Clarke claim) was sought through an ordinance in advance of the Privy Council hearing, allegedly in response to the ruling of the Supreme Court in Taylor in support of the capacity of the Governor to grant lands under the prerogative according to Chapman's private correspondence. ${ }^{119}$ The preamble

115 "Expedients Resorted to by the Imperial Government to Restrain the Governor in Making Grants of Lands in Excessive Quantities" (1852) (Wellington, Alexander Turnbull Library, Ms Paper 53/6, Ms Copy Micro 226, H S Chapman Papers) 10.

$116 R v$ Clarke (1848) (SC) (London, Kew, Public Record Office, Colonial Office 209/63) folios 146 and following; 17 of the report.

$117 R v$ Clarke (1848), above n 116, folios 146 and following; 17 of the report.

118 "Expedients Resorted to by the Imperial Government to Restrain the Governor in Making Grants of Lands in Excessive Quantities" (1852), above n 155, 10.

119 Chapman to Chapman senior (24 August 1849) Letter (Wellington, Alexander Turnbull Library, qMs0420) 743-744. 
to the resultant Ordinance for Quieting Titles to Land in the Province of New Ulster (as well as section 1) recognised the preponderance of Supreme Court thinking in favour of recognising the validity of Crown grants made under the public seal (Symonds, Taylor and Clarke). ${ }^{120}$ The preamble said, for instance, "and whereas certain cases have already been submitted to the judgment of the Supreme Court; but it is essential to the prosperity of the colony that such doubts should in all cases be removed with the least possible delay ...". Section 1 of the ordinance stipulated that "[e]very grant of land within the province of New Ulster, sealed with the public seal of the colony or province, and made before the passing of this Ordinance", on behalf of the Crown, would be "deemed and taken to be a good, valid, and effectual conveyance of the land" at issue.

To the extent that these legal questions about instructions and the prerogative have been considered extensively at all in the secondary literature, the view has been that it was very doubtful that instructions (published or not) had the force of law given Colonial Office views in the 1830s and 1840 s. ${ }^{121}$ Doubts about the legal force of instructions were voiced in certain quarters of Westminster officialdom but these doubts were not sufficient to prove determinative, often for reasons of political and administrative convenience. That is, as a matter of law, the question of instructions was left unresolved and assessments on what course of action to pursue in a given case were largely left to the realm of policy imperatives. The Supreme Court's judgments in Taylor and Clarke had effectively protected Grey's ordinance for dealing with New Ulster province titles from challenge, as they had opened the way for a pressing political need to stabilise the land claims question in New Zealand. In this context, however, the instructions given to Hobson at the very outset of New Zealand's Crown colony period continued to exercise London's attention. Clause 44 of the Royal Instructions said: ${ }^{122}$

And it is our will and pleasure that all the waste and uncleared lands within our said colony, belonging to and vested in us, which shall remain after making such reservations as before mentioned for the public service of our said colony of New Zealand, shall hereafter be sold and disposed of at one uniform price per acre, which price it is our pleasure shall from time to time be fixed and determined by such

120 An Ordinance for Quieting Titles to Land in the Province of New Ulster, 25 August 1849, session X, no. 4. Also Chapman to Chapman senior (26 October 1849) Letter (Wellington, Alexander Turnbull Library, Letters of H S Chapman qMs-0420) 758-759.

121 D B Swinfen Imperial Control of Colonial Legislation 1813-1865: A Study of British Policy towards Colonial Legislative Powers (Clarendon Press, Oxford, 1970) 78-82; Swinfen "The Legal Status of Royal Instructions to Colonial Governors" (1968) 13 Jur Rev 21, 22-23, 39: "Royal Instructions were, above all, the private orders of the Crown to the Royal Governor. As such they were a matter between the Crown and governor only. They were not officially published, and could not therefore be cited as legal authority in a court of law"; J C Beaglehole Royal Instructions to Governors (PhD Thesis, University of London, 1929) 654-655.

122 Russell to Hobson (5 December 1840) Royal Instructions Great Britain Parliamentary Papers 1841 (xvii (311)) 40 . 
instructions as we shall from time to time convey to you through one of our Principal Secretaries of State.

Two members of the Colonial Lands and Emigration Commission, T Murdoch and Sir Frederic Rogers, ${ }^{123}$ were of the view that clause 44 of the Royal Instructions to William Hobson, if still in force, may have sufficed to invalidate any colonial ordinance that purported to authorise the conveyance of land otherwise than by sale at a prescribed price, such as George Grey's "Ordinance for Quieting Titles to Land in the Province of New Ulster" (passed by the legislative council in New Zealand on 25 August 1849). ${ }^{124}$ However, Earl Grey was clear that he was "not prepared to bring in a bill for settling this matter by the authority of Parlt under any circumstances". He continued: "I must therefore speak to Mr Merivale on the subject before any case is sent to the law officers".125 With these encouraging pragmatic policy indications from Earl Grey, T Frederick Elliot recommended confirming the ordinance in question without referring it to the law officers even though an extensive case had been drawn up for their attention. ${ }^{126}$ In spite of the Colonial Office's confirmation of the ordinance, however, final resolution of the old land claims issue relating to FitzRoy's "penny an acre" proclamation of October 1844 eluded the northern districts of New Zealand until the late 1850 s. ${ }^{127}$ Nonetheless, these historical claims to land were increasingly circumscribed administratively, as the Crown engaged in ambitious "purchases" from Maori (predominantly in the South Island) and new legislative regimes were established to deal with the allocation of lands in New Zealand, particularly in the wake of the New Zealand Constitution Act 1852 (as with the Public Reserves Act 1854 for instance). ${ }^{128}$ As an afterword, it is noteworthy that, in the context of the earlier Supreme Court jurisprudence, section 72 of the New Zealand Constitution Act stipulated that it would "be lawful for Her Majesty to regulate [the] Sale, Letting,

123 Sir Frederic Rogers had been a fellow of Oriel College, Oxford, and was appointed to the Board of Colonial Lands and Emigration in London in May 1846.

124 Murdoch and Rogers to Merivale (7 June 1850) (London, Kew, Public Record Office, Colonial Office $323 / 69$ ) folios 225-232.

125 Earl Grey (13 June 1850) Minute (London, Kew, Public Record Office, Colonial Office 323/69) folios 232a.

126 Case [for Law Officers of the Crown] (London, Kew, Public Record Office, Colonial Office 323/69) folios 233-239a. The royal instructions to Hobson of 5 December 1840 purported to be issued at the advice of the Privy Council and were given in the context of New South Wales and Van Diemen's Land Act 1840 (UK), 3 \& 4 Vict, c 62 (which authorised the Queen to erect into a separate colony any islands then dependent upon New South Wales and to constitute a Legislative Council for the new colony). For official confirmation of the ordinance see Earl Grey to Grey (13 August 1850) Great Britain Parliamentary Papers 1850 (vi (1280)).

127 This extended but under-researched denouement could comprise an entire study in itself. Refer to Francis Dillon Bell "Memorandum by the Chief Commissioner of Land Claims on the Land Claims Settlement Extension Bill" [1858] AJHR c 2, 2-4. Also J S Marais The Colonisation of New Zealand (Oxford University Press, London, 1927) 283.

128 New Zealand Constitution Act 1852, 15 \& 16 Vict, c 72. 
Disposal and Occupation [of waste lands (where aboriginal title had been extinguished)] by Instructions to be issued under the Signet and Royal Sign Manual", until the General Assembly of New Zealand had enacted laws regulating such lands. To that extent then, the force of instructions was given a statutory fillip at the imperial level although colonial legislation would increasingly ease out the relevance of such instructions throughout the remainder of the nineteenth century. ${ }^{129}$

\section{CONCLUSION}

This article has endeavoured to re-introduce the "forgotten" cases of Scott v Grace and Taylor and to invite consideration of their specific historical contexts. These legal proceedings indicate that controversial questions concerning the extent of the New Zealand governor's ability to grant lands outside of the provisions of local ordinances and even an imperial statute exercised both policymakers (in London and Auckland) as well as colonial judges and other participants in the cases. The judgments of the Supreme Court in Scott v Grace, Taylor, and Clarke gave rise to a policy lacuna whereby troublesome grants issued during FitzRoy's tenure as governor were upheld on the basis of the prerogative. This stance on the prerogative to grant property undermined, in its turn, the degree to which his successor, George Grey, could rely on court proceedings and prior ordinances (the Land Claims Ordinance 1841 for instance) to render such grants invalid in the first place. In one context, a grant to seabed and foreshore was involved (Attorney-General $v$ Whitaker \& Anor and Taylor). Ultimately, a combination of measures presented themselves: the New Zealand Company extinguished certain FitzRoy grants through purchase; others were recognised as valid in New Ulster province pursuant to an ordinance in 1849. Although Symonds has overshadowed these neglected cases, they continue to provide important insights into the manner with which colonial judges and imperial officials attempted to confront the vexed questions of land claims as well as the nature of the Crown prerogative and the extent to which it might have been constrained. They represent a prelude to subsequent legislative and policy efforts to qualify the reach of prerogative powers in colonies, and, to that extent alone, they deserve remembering as a prelude to the manner in which the New Zealand Constitution Act 1852 endeavoured to ensure legislation as the principal means for managing the allocation of territorial space. Scott $v$ Grace also illustrates the receptivity of Chapman to the use of United States' case law in colonial New Zealand although this essay has cautioned against seeing such use as uncontentious with brief reference made to disputes concerning the use and meaning of Marshall court jurisprudence on "native title".

129 See also New Zealand Constitution Act 1852, 15 \& 16 Vict, c 72, s 79, which provided that: "It shall be lawful for Her Majesty, by any such Letters Patent as aforesaid, or Instructions under Her Majesty's Signet and Sign Manual, or signified through One of Her Majesty's Secretaries of State, to delegate to the Governor any of the Powers herein-before reserved to Her Majesty respecting the Removal of Superintendents of Provinces and the Regulation of the Sale, Letting, Disposal, and Occupation of Waste Lands, the Establishment of Municipal Corporations, and the Preservation of aboriginal Laws, Customs, and Usages." 